\title{
Kunst als geneesmiddel
}

Deijen, Zuzanka

Correspondentieadres:

zuzanka deijen@live.nl

\section{Samenvatting}

Kunsttherapie is in 1942 voor het eerst beschreven en is hiermee een relatief jonge discipline. Er wordt nog volop onderzoek naar gedaan en de waarde van kunst in therapie is niet eenduidig. In onderstaande script worden meningen en conclusies uit diverse bronnen beschreven. Op basis hiervan kunnen we ons een idee vormen over de toepasbaarheid van kunst als geneesmiddel. Een voorzichtige conclusie kan zijn dat kunst vooral toegepast wordt in de geestelijke gezondheidszorg.

\section{Geschiedenis}

Kunsttherapie is een vrij jonge discipline.

De wortels liggen in de behandeling van psychiatrische patiënten in de late $18 \mathrm{e}$ eeuw en in een her-evaluatie van de werking van niet-westerse kunst, kunst van ongetrainde kunstenaars en die van mensen met een psychische stoornis.

Kunsttherapie als echte beroepsvorm begon op de helft van de 18e eeuw in Engelssprekende en Europese landen. De eerste kunsttherapeuten die hun werk hebben vastgelegd en gepubliceerd erkenden, in verschillende mate, de invloed van esthetiek, psychiatrie, psychoanalyse, revalidatie, en vroegschoolse educatie, kunst en onderwijs op hun werk.

De Britse artiest Adrian Hill [1] bedacht de term kunsttherapie in 1942. Hill, die in een sanatorium herstellende was van tuberculose, ontdekte de therapeutische waarde van tekenen en schilderen tijdens de revalidatie. Hij schreef: "de waarde van kunsttherapie ligt in het volledig in beslag 
nemen van de geest en ook de vingers, waardoor de vaak afgeremde patiënt zijn creatieve energie de vrije loop kan geven" [2]. Dit stelde de patiënt in staat een sterke verdediging op te bouwen tegen zijn tegenslagen. Hij raadde zijn medepatiënten aan om creatief aan de slag te gaan.

Daarmee begon zijn carrière in de kunsttherapie die werd vastgelegd in 1945 in zijn boek Art Versus Illness.

De artiest Edward Adamson ging na de Tweede Wereldoorlog samenwerken met Adrian Hill om zijn werk uit te breiden naar de Britse psychiatrische ziekenhuizen.

Andere vroege voorstanders van kunsttherapie zijn onder andere E.M. Lyddiatt, Michael Edwards [3] en Rita Simon. De British Association of Art Therapists werd gesticht in 1964 .

Pioniers van de kunsttherapie uit de Verenigde Staten Margaret Naumburg [4] en Edith Kramer [5] begonnen hun uitvoering rond dezelfde tijd als Hill. Naumburg, een docent, vond dat "kunsttherapie psychoanalytisch georiënteerd is en dat vrije kunst uitdrukking een vorm van symbolische taal is die leidt tot een toename van verbalisatie in de therapie" [2]. Edith Kramer, een kunstenares, wees op het belang van het creatieve proces, psychologische verdediging en artistieke kwaliteit: "sublimatie wordt bereikt als vormen gecreëerd worden die succesvol woede, angst of pijn bevatten"[2].Andere vroege voorstanders van kunsttherapie in de VS zijn onder andere Elinor Ulman, Robert "Bob" Ault [6], en Judith Rubin [7]. De American Art Therapy Association [8] werd gesticht in 1969.

Professionele nationale verenigingen van kunsttherapie bestaan tegenwoordig in veel landen, waaronder Brazilië, Canada, Finland, Israël, Japan, Nederland, Roemenië, Zuid Korea, en Zweden. Internationale netwerken helpen bij het vaststellen van algemene standaarden voor onderwijs en praktijk.

\section{Kunsttherapie en Outsider art}

De term 'Art Brut' is voor het eerst gebruikt in 1948 door de Franse kunstenaar Jean Dubuffet voor kunst die niet door professionele kunstenaars wordt gemaakt. Dubuffet gebruikte de term voor kunstwerken die gemaakt waren door mensen die deels of geheel buiten de maatschappij staan, zoals psychiatrische patiënten, verstandelijk gehandicapten of gedetineerden. De Engelse vertaling 
'Outsider Art' werd voor het eerst gebruikt door kunstcriticus Roger Cardinal in 1972.

Deze kunstvorm houdt dus in dat de kunst gemaakt wordt buiten de grenzen van de gevestigde normen en waarden van de cultuur om. Dubuffet focuste zich voornamelijk op kunst gemaakt door mensen de buiten de bekende kunstwereld, zoals psychiatrische patiënten, kinderen en primitieve volkeren. Vanuit deze in artistiek opzicht vrije uitgangspositie probeerde hij zichzelf los te maken van de conventionele principes die nog altijd werden gedicteerd door de Ecole de Paris. Dubuffet durfde, puur voor de creativiteit, dom en onsamenhangend te zijn. Hij wilde het gewone leven in ere herstellen, de poëzie laten zien van het alledaagse leven. Daarvoor schiep hij een fantastische, humoristische wereld, uitgevoerd in aardse tinten. Net zoals veel van zijn tijdgenoten maakte Dubuffet gebruik van aardse materialen zoals cement, gips, zand of lijm, waarmee hij dus ook onder de materiekunstenaars kan worden gerekend. Andere bekende namen uit de Outsiderskunst zijn Hundertwasser en Arnulf Rainer.

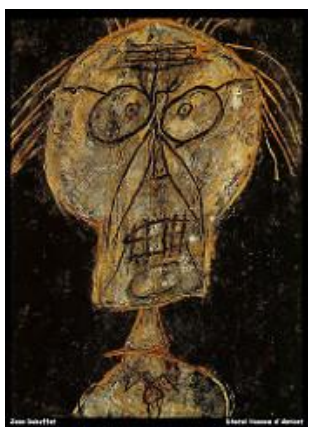

Jean Dubuffet

Het gemeenschappelijke thema van de groep was de inspiratie die ze putten uit kindertekeningen, folklore en mythen, dromen en primitieve kunst. Vanuit die achtergrond schilderden ze spontaan, persoonlijk en vanuit het onbewuste (de zogenaamde écriture automatique). Een andere groep die op deze manier te werk ging was Cobra. De Cobraleden maakten wilde, kleurrijke abstract-afiguratieve schilderijen met bijvoorbeeld maskers, vervormde figuren, trollen en geesten, labyrinten, demonen en duiveltjes als herkenbare elementen. Net als Dubuffet en andere outsiderkunstenaars waren ze overtuigd van hun missie om zich los te maken van de principes van de Ecole de Paris. De term die Dubuffet gebruikt is echter erg specifiek, terwijl de Engelse benaming 'Outsider Art' een veel bredere context heeft. Hieronder vallen ook bepaalde autodidactische kunstenaars en naïeve kunstenaars die nooit in een 
instituut hebben gezeten. Kenmerkend voor de Outsider kunstenaars is dat zij nauwelijks of geen contact hebben met de 'mainstream' kunstwereld of kunstinstellingen. Vaak wordt hun kunst pas na hun dood ontdekt. In de meeste gevallen illustreert Outsider Art extreme mentale toestanden, onconventionele ideeën, of uitgebreide fantasiewerelden.

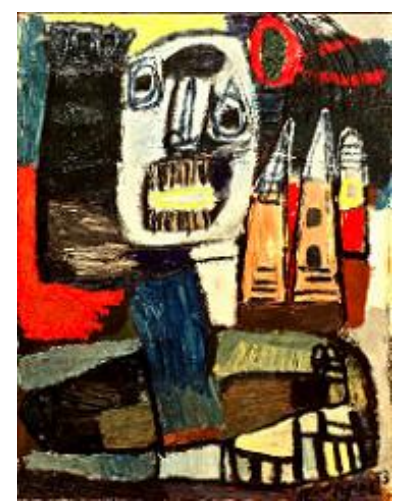

Karel Appel - Cobra

De interesse in de kunst van geesteszieken, kinderen en dat van de gewone mens (of boer), werd voor het eerst zichtbaar in de werken van "Der Blaue Reiter" [9]: Wassily Kandinsky [10], Auguste Macke [11], Franz Marc [12], Alexej Jawlensky [13] en meer. Wat de kunstenaars waarnamen in het werk van deze groep was een expressieve kracht die voortkwam uit hun gebrek aan verfijning. Voorbeelden hiervan werden gereproduceerd in 1912 in het eerste en enige nummer van hun publicatie, Der Blaue Reiter Almanac. Tijdens de Eerste Wereldoorlog werd Macke in 1914 bij Champagne gedood en Marc werd in 1916 bij Verdun gedood. De leegte achtergelaten door deze sterfgevallen werd in zekere mate gevuld door Paul Klee, die inspiratie bleef putten uit deze 'primitieven'.

Deze interesse in de kunst uit het gekkenhuis bleef groeien in de jaren 20 van de 19e eeuw. In 1921 publiceerde Dr. Walter Morgenthaler zijn boek Ein Geisteskranker als Künstler [14] (Een geesteszieke als Kunstenaar) over een psychotische, verstandelijk gehandicapte die hij behandelde. Wölfli was spontaan begonnen met tekenen, deze bezigheid leek hem te kalmeren. Zijn meest opmerkelijke werk was een geïllustreerd epos van 45 volumes, waarin hij zijn eigen imaginaire levensverhaal vertelde. Met 25.000 pagina's, 1.600 illustraties en 1.500 collages, is het een monumentaal werk. Wölfli produceerde ook een groot aantal kleinere werken, waarvan sommige werden verkocht of als cadeau gegeven. Zijn werk is te zien op de Adolf Wölfli Foundation in het Museum voor Schone Kunsten in Bern. 
Een belangrijk moment was de publicatie van Bildnerei der Geisteskranken [15] (kunstenaarstalent van geesteszieken) in 1922, door Dr. Hans Prinzhorn. Dit was de eerste formele studie van psychiatrische werken op basis van een compilatie van duizenden voorbeelden uit de Europese instellingen. Het boek en de kunstcollectie kregen veel aandacht van de avant-garde kunstenaars van die tijd, bijvoorbeeld van Paul Klee, Max Ernst, en Jean Dubuffet.

Mensen met een artistieke opleiding evenals beroemde kunstenaars zijn niet immuun voor geestesziekten en kunnen ook worden geïnstitutionaliseerd.

Bijvoorbeeld William Kurelek, later onderscheiden met de Orde van Canada voor zijn artistieke levenswerk. Als jonge man werd hij toegelaten tot het Maudsley Psychiatric Hospital, waar hij werd behandeld voor schizofrenie. In het ziekenhuis schilderde hij en produceerde The Maze, een donkere uitbeelding van zijn gemartelde jeugd. Hij werd overgebracht van de Maudsley aan Netherne Ziekenhuis van november 1953 tot januari 1955 om te werken met Edward Adamson (1911-1996), een pionier op het gebied van beeldende therapie, en bedenker van de Adamson Collection.
Dubuffet vond dat 'cultuur', dat is de gevestigde kunst cultuur, erin was geslaagd om elke nieuwe ontwikkeling te assimileren in de kunst en hierdoor elke soort van kracht die het gehad zou kunnen hebben weg heeft genomen. Het resultaat was het verstikken van echte uitdrukking. Art Brut was zijn oplossing voor dit probleem, alleen Art Brut was immuun voor de invloeden van cultuur, immuun voor geassimileerd worden, omdat de kunstenaars zelf niet bereid of in staat waren om te worden geassimileerd.

De belangstelling voor 'buitenstaander' praktijken van de twintigste-eeuwse kunstenaars en critici kan gezien worden als onderdeel van de steeds nadrukkelijkere afwijzing van gevestigde waarden binnen het moderne milieu. Het begin van de 20e eeuw gaf aanleiding tot het Kubisme en de Dada, Constructivistische en Futuristische bewegingen in de kunst, die allemaal betrokken zijn bij een dramatische beweging weg van culturele vormen van het verleden. Dadaïst Marcel Duchamp, bijvoorbeeld, verliet 'schilderkunstige' techniek zodat het toeval een rol kreeg bij het bepalen van de vorm van zijn werken of om simpelweg bestaande 'kant en klare' objecten als kunst mogelijk te maken en hier een diepere betekenis aan te geven. 
Kunstenaars als Pablo Picasso, keken buiten de tradities van hoge cultuur voor inspiratie, tekende de artefacten van 'primitieve' samenlevingen, de ongeschoolde kunstwerken van kinderen en vulgaire reclame graphics. Het opkomen voor het Art Brut door Dubuffet, kunst van de krankzinnige en andere randgevallen, is het zoveelste voorbeeld van de avant-garde kunst die gevestigde culturele waarden uitdaagt.

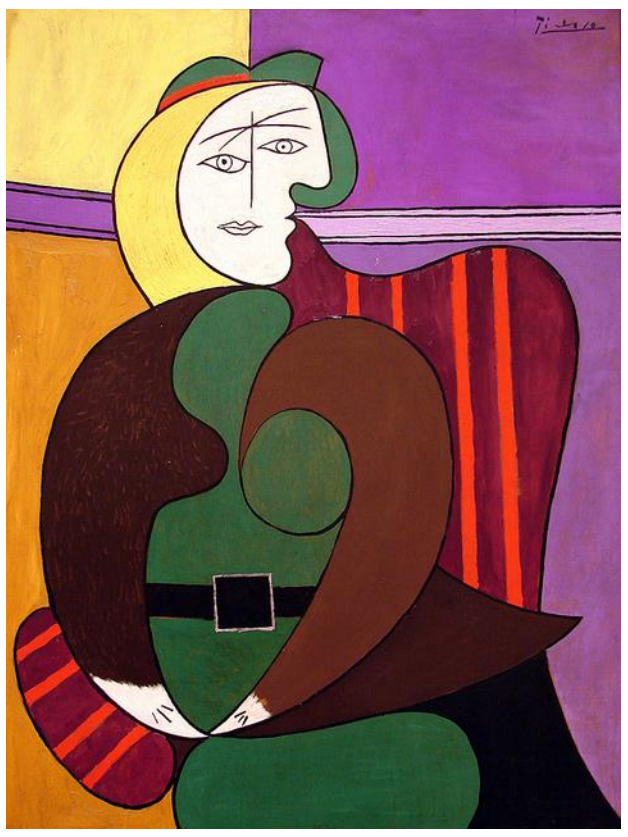

\section{Pablo Picasso}

Beide begrippen zijn echter meerdere malen bekritiseerd om hun sociale en persoonlijke impact op patiënten en kunstenaars. Kunsttherapeuten zijn ervan beschuldigd niet genoeg nadruk te leggen op de artistieke waarde en betekenis van de werken van de kunstenaars, waardoor ze dus alleen naar het werk kijken vanuit een medisch perspectief. Dit leidde tot een misvatting over Outsider Art praktijk, met daarbij aandacht voor therapeutische vraagstukken binnen het gebied van de esthetische discussie. Outsider Art, daarentegen, is vaak negatief beoordeeld voor de benaming van het werk van de artiest, neem bijvoorbeeld de vergelijking artist $=$ genius $=$ insane .

\section{Kunst als therapie}

\section{Alain de Botton \& John Armstrong}

"We horen vaak dat kunst heel belangrijk is, maar eigenlijk nooit waarom dat zo is" [16]. Alain de Botton en John Armstrong zijn van mening dat kunst ons kan helpen bij de meest intieme, maar zeer herkenbare dilemma's: "Waarom bevalt mijn werk me niet meer? Waarom lijken andere mensen een veel spannender leven te leiden? Hoe kan ik mijn relatie met anderen verbeteren? Waarom word ik zo depressief van de politiek?" [16] De Botton en Armstrong schreven een boek dat een nieuwe methode introduceert om naar kunst te kijken: als een vorm van therapie, vol oplossingen voor tal van levensvragen.

- Waar dient kunst voor?

De moderne wereld beschouwt kunst als iets heel belangrijks, iets wat heel dicht bij 
de zin van het leven staat. Bewijzen van deze opvatting kun je vinden bij de opening van nieuwe musea, bij de overheidsbegrotingen op het gebied van kunst en cultuur, in de wens onder kunsthoeders om kunst beter beschikbaar te maken, in het prestige van academische kunsttheorieën en de hoge prijzen waarvoor kunst op de commerciële markt wordt verhandeld.

Kunst kan een gereedschap zijn en we moeten ons duidelijker focussen op wat voor soort gereedschap het is en wat je ermee kan doen.

Net als andere gereedschappen kan kunst onze vaardigheden en mogelijkheden vergroten. Dankzij gereedschap kunnen we meer doen dan met alleen onze handen en onze zintuigen. Kunst compenseert onze aangeboren gebreken, in dit geval van de geest. Gebreken die we kunnen omschrijven als psychische tekortkomingen. Het boek van de Botton en Armstrong stelt dat kunst "een therapeutisch medium is dat ons kan begeleiden, vermaken en troosten, waardoor we instaat zijn betere versies van onszelf te worden." Om achter het doel van kunst te komen, moeten we vragen welke dingen onze geest en emotie nodig hebben om beter te kunnen functioneren.
Bij welke psychologische beperkingen kan kunst van pas komen? Er zijn 7 beperkingen benoemd en daarbij 7 functies van kunst.

- De 7 functies van kunst

1 - Herinneren

2 - Hoop

3 - Leed

4 - Weer in balans komen

5 - Zelfinzicht

6 - Ontwikkeling

7 - Waardering

\section{$\underline{1 . \text { Herinneren }}$}

We vergeten vaak wat er echt toe doet. We kunnen belangrijke, maar moeilijk te begrijpen ervaringen lastig vasthouden. Kunst is een middel om ons geheugen te verbeteren. Het zorgt ervoor dat we de goede dingen van onze ervaringen onthouden en gebruiken. Kunst is een manier om dierbare dingen en onze beste inzichten in goede staat te houden en voor iedereen toegankelijk te maken. 


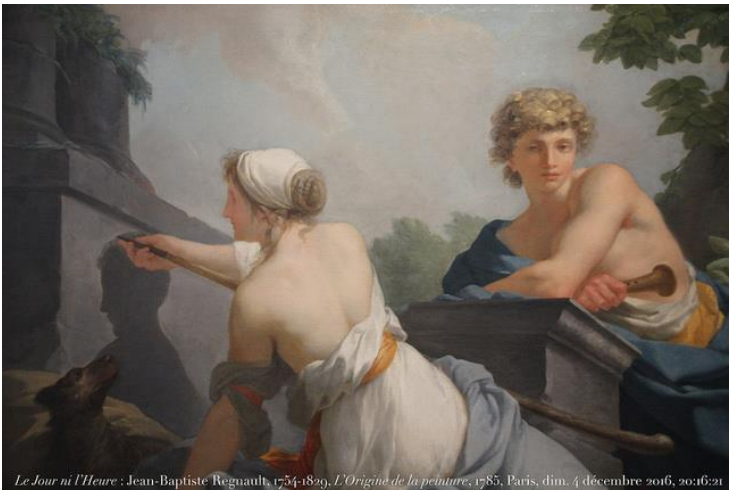

Jean-Baptiste Regnault - Dibutade ou l'origine de la peinture

Hier zie je een verhaal van de Romeinse schrijver Plinius de Oudere afgebeeld. Een verliefd stel moet afscheid van elkaar nemen en als herinnering aan haar geliefde tekent de vrouw de omtrekken van zijn schaduw. Het schilderij is aangrijpend. De twee hebben net hun laatste dag samen doorgebracht. De vrouw maakt een tekening van haar geliefde, zodat ze hem tijdens zijn afwezigheid beter voor de geest zal kunnen halen. Het inzicht dat het schilderij geeft is psychologisch. Regnault stelt de essentiële vraag waarom kunst er voor ons toe doet en het antwoord is: kunst stelt ons in staat om een levenstaak te vervullen; geliefde dingen vasthouden als ze eenmaal zijn verdwenen.

\section{Hoop}

We neigen er vaak naar de hoop snel op te geven: we zijn namelijk overgevoelig voor de vervelende kanten van het bestaan. We verspelen goede kansen op succes doordat we niet inzien dat we in bepaalde situaties gewoon alleen maar door moeten zetten. Kunst geeft ons hoop. Kunst laat ons aangename, vrolijke dingen zien. Het lijkt te weten dat we te gemakkelijk wanhopen.

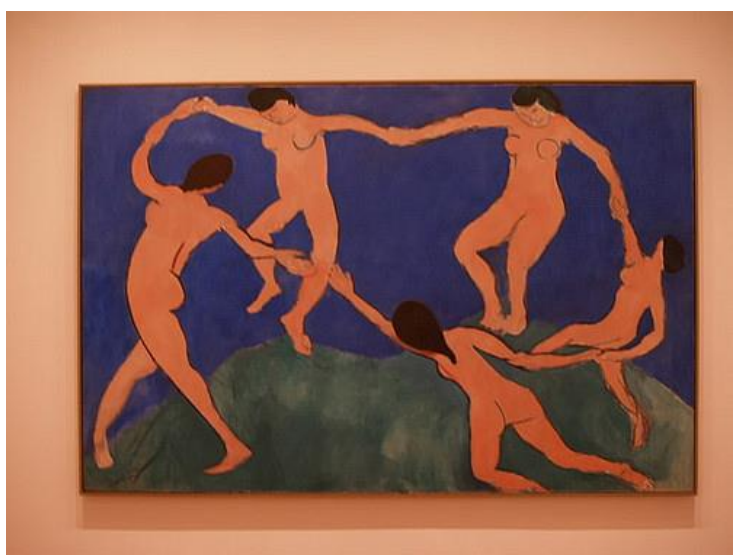

Henri Matisse - Dans

De dansers in het schilderij van Matisse zullen niet beweren dat deze wereld volledig zonder problemen is, maar hun houding straalt een aanmoediging uit. Ze zetten ons in contact met een vreugdevol, zorgeloos deel van onszelf dat ons kan bijstaan in de omgang met onvermijdelijke vernederingen en afwijzingen.

\section{Leed}

We hebben gauw het gevoel dat we alleen zijn en achtervolgd worden door problemen, aangezien we geen idee hebben hoeveel ellende normaal is. We raken te 
snel in paniek, doordat we een verkeerd beeld hebben van de betekenis van onze problemen. We zijn eenzaam. Niet omdat we niemand hebben om mee te praten, maar die mensen zijn niet diepzinnig, oprecht en geduldig genoeg om zich in ons leed in te leven. Dat komt deels doordat de wijze waarop we ons verdriet tonen waardigheid mist. Kunst is een bron van waardig verdriet. Het herinnert ons eraan dat er in een goed leven ook ruimte mag zijn voor verdriet, zodat we ons minder druk maken over onze problemen en beseffen dat ze een onderdeel vormen van een nobel bestaan.

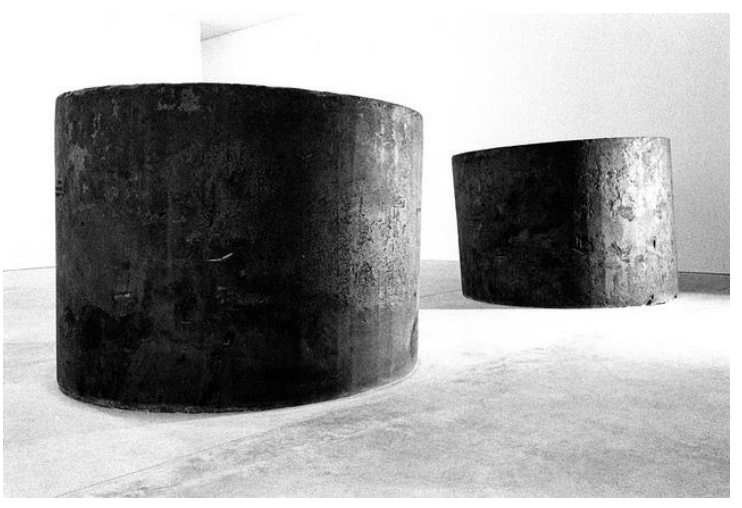

Richard Serra - Fernando Pessoa

Fernando Pessoa doet geen enkele poging om somberheid te verbergen. De buitenkant van onze samenleving is vaak vrolijk en positief . Als je iemand een probleem voorlegt, zal hij of zij naar een oplossing zoeken en je een zonnig beeld proberen te schetsen. Maar Serra's werk ontkent deze problemen niet en probeert ons niet op te vrolijken. Het vertelt dat zorgen onlosmakelijk met het leven zijn verbonden. De grote schaal en het monumentale karakter van het werk bevatten een boodschap van de normaalheid van leed. Fernando Pessoa is vernoemd naar de Portugese dichter die alles van het menselijk leed af wist. Het benadrukt dat we de meest sombere en ernstige emoties moeten erkennen en een plek moeten geven. Je moet je niet opsluiten met zulke gevoelens en het werk verklaart dan ook dat deze gevoelens een centraal en universeel kenmerk van het leven zijn.

\section{Weer in balans komen}

We zijn uit balans en hebben geen oog meer voor onze beste kanten. We zijn niet slechts één persoon. We hebben meerdere ikken en beseffen dat sommige hiervan beter zijn dan andere. Onze betere ikken komen we vaak bij toeval tegen en te laat. We hebben te weinig wilskracht om onze idealen te bereiken. Kunst zorgt voor balans. Het toont op een bijzonder heldere manier de essentie van onze goede eigenschappen en laat die in diverse vormen zien om ons te helpen bij het weer in balans brengen van ons karakter en het 
benutten van onze mogelijkheden.

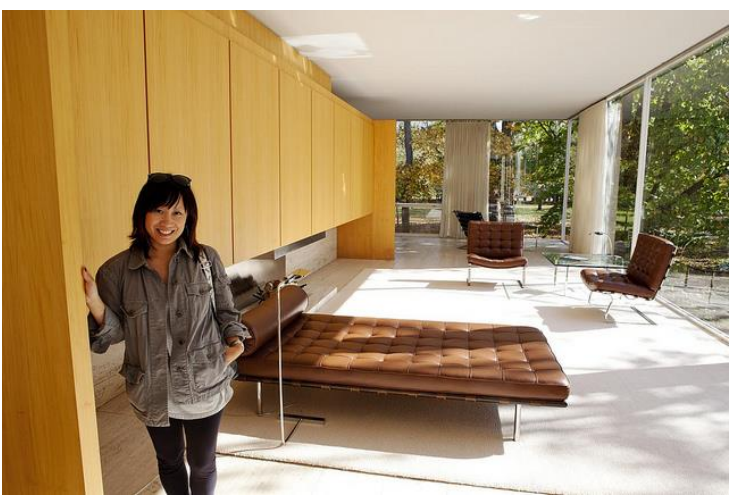

Ludwig Mies van der Rohe - Farnsworth House

Stel dat we in een manier van leven zijn gerold die te intens is, met te veel prikkels en afleiding. Zodra onze werkdag begint, hebben we nauwelijks nog tijd om ergens over na te denken, 's Avonds keren we echter terug naar bijvoorbeeld een volmaakt symmetrisch, ordelijk huis met één slaapkamer in een voorstad van Chicago. Wanneer we door de grote ramen naar buiten kijken, krijgen we de kans om weer in contact te komen met onze solitaire, peinzende $\mathrm{ik}$, dat ons anders ontglipt zou zijn. Het regelmatige ritme van de stalen raambalken brengt onze diep weggestopte rustige kant weer naar boven. Bij het zien van de fijne plooien van een gigantisch gordijn dat de elegante woonruimte omsluit, weten we weer hoe belangrijk tederheid is. Een eenvoudig terras met kalkstenen tegels doet bij ons de behoefte aan een bescheiden, teerhartig soort geluk opkomen. Een kunstwerk helpt ons weer in contact te komen met de verwaarloosde kanten van ons karakter.

\section{$\underline{\text { 5. Zelfinzicht }}$}

Het is moeilijk om onszelf te leren kennen: we zijn een raadsel voor onszelf en kunnen daardoor niet goed aan anderen uitleggen wie we zijn of waarom ze ons aardig zouden moeten vinden. Kunst is een leidraad voor zelfkennis. Kunst kan helpen om te ontdekken wie we diep van binnen zijn. Vaak kunnen we dat niet in woorden uitdrukken. Wel kunnen we dan een kunstvoorwerp ophouden en met zekerheid zeggen: 'dit ben ik.'

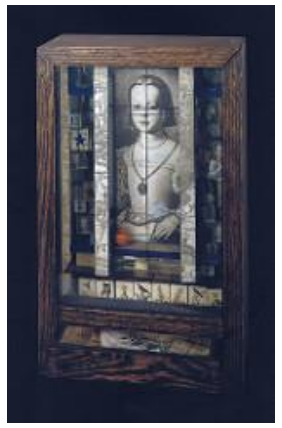

Joseph Cornell - Zonder titel

Stel dat onze aandacht wordt getrokken door dit doosje van Joseph Cornell. Waar komt dat vreemde gevoel van herkenning vandaan? Welk deel van onszelf is als dat 
doosje? Het doosje toont hoe we

verschillende elementen van één identiteit in harmonie kunnen brengen. Het doosje zegt: 'ik ben gemaakt van een web van relaties.' We zijn gevoelig voor het idee van een ingewikkelde reeks symbolen die samen een leven schetsen. Het doosje bevat een archief van een persoonlijkheid. Iets veranderlijks en onduidelijks als een persoonlijke identiteit wordt hier op een beheersbare en bruikbare manier gepresenteerd. In het ideale geval zou er een kunstenaar bestaan die voor ieder van ons een doosje kon maken, zodat we onszelf beter konden leren kennen en een middel hadden om aan anderen beter duidelijk te maken wie we zijn.

\section{Ontwikkeling}

Veel ervaringen, mensen, plaatsen en perioden die ons iets belangrijks te bieden hebben, verwerpen we omdat ze in de verkeerde verpakking zitten en we er niets mee kunnen. Onze oordelen zijn vaak oppervlakkig en vooringenomen. We vinden dingen snel 'vreemd' en dat is een veel te defensieve houding. Kunst is een leidraad voor het uitbreiden van onze ervaring. Kunst is een zeer verfijnde verzameling van ervaringen van anderen, die in mooie, goed georganiseerde vormen gepresenteerd worden. Het kan enkele van de sprekendste vormen van uitingen van andere culturen tonen, waardoor we meer inzicht krijgen in onszelf en in onze wereld. Eerst lijken veel kunstwerken slechts 'anders' te zijn, maar we ontdekken dat ze ideeën en opvattingen kunnen bevatten die we ons op een zodanige manier eigen kunnen maken dat ze ons verrijken. Niet alles wat we nodig hebben om een betere versie van onszelf te worden ligt binnen handbereik.

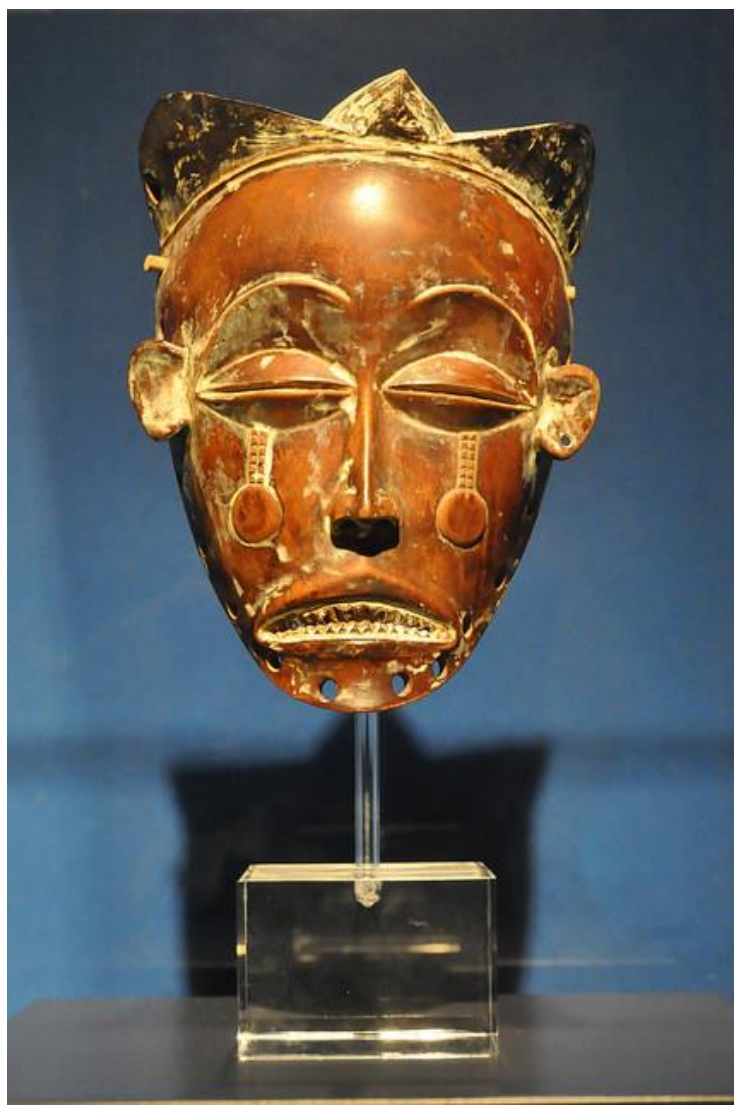

Mwana Pwo-masker 
Iemand kan zich ongemakkelijk voelen bij het zien van een Afrikaans masker dat in Oost-Angola wordt gebruikt bij het inwijdingsritueel van jongens. Als we zouden vragen wat er zo weerzinwekkend is aan dit werk, zou de persoon in kwestie het probleem waarschijnlijk niet zozeer aan de uitvoering toeschrijven, maar aan de negatieve associaties (van persoonlijke oorsprong) die aan het genre kleven waartoe dit werk behoord. Als we zouden doorvragen, zou bijvoorbeeld kunnen blijken dat Afrikaanse maskers hem doen denken aan een film over voodoo die hij ooit heeft gezien en aan een zweverige kennis die maar blijft doorzeuren over de spirituele superioriteit van Afrika. Afkeer van kunstgenres vindt vaak zijn oorsprong in zeer beangstigende ervaringen. Omdat deze negatieve emoties allerlei defensief gedrag opwekken dreigen ze een onredelijk groot deel van ons leven te bederven. We komen niet verder in het leven als we blijven generaliseren bij kwesties die eigenlijk uitzonderingen zijn. Je bezighouden met kunst verschaft materiaal dat onze defensieve verveling en angst uitdaagt en biedt mogelijkheden daar beter mee om te gaan. We moeten meer openstaan voor het vreemde gevoel dat we in bepaalde omstandigheden ervaren.

\section{Waardering}

We zijn ongevoeliger geworden doordat alles zo vertrouwd is en leven in een door de commercie beheerste wereld die de nadruk legt op glamour. Vaak zijn we ontevreden omdat het leven saai is. We worden gekweld door het idee dat er ergens anders meer te beleven valt. Kunst helpt ons weer gevoelig te worden. Het haalt onze schil weg en redt ons van de onverschilligheid waarmee we gewend zijn alles om ons heen te bekijken. We worden weer ontvankelijk en kijken op nieuwe manieren naar het oude. Kunst maakt ons duidelijk dat nieuwigheid en glamour niet de enige oplossingen zijn.

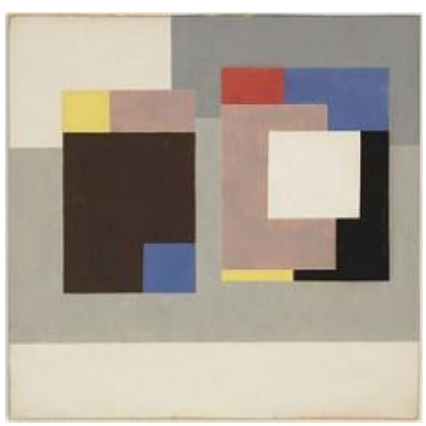

Ben Nicholson - 1943 (painting)

Het werk van Ben Nicholson is een hulde aan het genot dat eenvoudige dingen kunnen bieden. Nicholson ging geheel op in het zorgvuldig rangschikken van de elementen, op zoek naar een bepaald soort harmonie. Het werk is het product van een 
geest die van kleine manoeuvres houdt en makkelijk vertaald kan worden naar huishoudelijke klusjes of rustige hobby's. Het kunstwerk brengt deze gemoedstemming en momenten van tevreden concentratie in de publieke sfeer, waardoor die een kunstzinnig imago krijgt. Als we zien hoe ons leven over het algemeen verloopt, moeten we blij zijn met alle betrouwbare, bescheiden en goedkope genoegens die het te bieden heeft. Het werk neemt het simpelweg op een elegante manier op voor een aantal van onze enigszins verwaarloosde vaardigheden, en zo helpt het ons meer ontspannen in het leven te staan.

\section{De kunst van gezondheid - BETER}

\section{Consortium onderzoek}

Het BETER Consortium, een

samenwerkingsverband tussen specialisten uit de kunst- , zorg- en wetenschappelijke sector, onderzocht de impact van kunst en placebo's voor kunst op de gezondheid. Zo wil BETER de discussie over het belang van kunst, de kwaliteit van zorg en de meetbaarheid van beide stimuleren [17]. BETER, de kunst van gezondheid was een interactieve onderzoeksexpositie in het Medisch Centrum Haaglanden in Den Haag, van 9 november 2012 t/m 8 februari
2013. Voor het eerst werd op wetenschappelijke wijze onderzocht of kunst effect op de gezondheid heeft. Omdat de meeste medicijnen worden getest door middel van placebomedicijnen heeft BETER voor het onderzoek gebruik gemaakt van placebokunst. Wat ze bedoelen met een placebo voor kunst is iets dat zich voordoet als kunst maar het niet is. Hiermee wordt bedoeld: kunstwerken waarvan de maker vindt dat er helende elementen inzitten. Bij een placebo stelt de kunstenaar dat dit niet het geval is.

De onderzoeksvraag van BETER was: 'heeft kunst een positieve uitwerking op de gezondheid van mensen?'

Ze hebben verschillende soorten onderzoeken gedaan:

- $\quad$ Neurologisch onderzoek

- $\quad$ EEG-onderzoek: hoe reageren hersenen op (placebo)kunst?

- $\quad$ Fysiologisch onderzoek: hoe reageren lichamen op (placebo)kunst?

- $\quad$ Welzijnsonderzoek: hoe kan kunst de ervaringen van de omgeving bij patiënten positief beïnvloeden?

- $\quad$ Thuisonderzoek

- $\quad$ Placebo-onderzoek

Ik zal alleen ingaan op de onderzoeken die betrekking hebben op mijn 
onderzoeksvraag.

- Fysiologisch onderzoek

Het BETER consortium voerde een

fysiologisch onderzoek uit waarbij

gekeken werd of (placebo) kunst

fysiologische reacties kan veroorzaken

[18]. Proefpersonen werden in een rolstoel door een parcours gereden, waarbij zij naar kunstwerken of placebokunstwerken keken terwijl zij waren aangesloten op apparatuur die registreerde wat er gebeurde met hun ademhalingsfrequentie, zweetsecretie/huidgeleiding, hartslag, spanning van de gezichtspieren (lachspieren) en huidtemperatuur. Uit de resultaten van dit onderzoek blijkt dat de huidgeleiding/zweetsecretie duidelijk meer daalde tijdens het kijken naar kunst dan tijdens het kijken naar placebokunst. Deze daling geeft ontspanning aan. Hetzelfde effect werd gevonden bij de huidtemperatuur en hartslag. Kunst lijkt dus een rustgevend effect te hebben.

- Neurologisch onderzoek

In samenwerking met Hersencentrum onderzocht het BETER Consortium de invloed van kunst op hersenactiviteit [19]. De hypothese werd onderzocht dat kijken naar kunst zorgt voor een toename in de hoeveelheid thèta-activiteit in het centraalfrontale gedeelte van de neocortex. De veronderstelling was dat de thèta-activiteit toeneemt wanneer een persoon betrokken is in een creatief proces. Proefpersonen kregen steeds twee reeksen met beelden te zien; een reeks kunstbeelden en reeks placebokunstbeelden. Met een EEGmeting werd de thèta-activiteit gemeten.

De hoeveelheid thèta-activiteit beïnvloedde de snelheid van de reeksen: als er weinig thèta-activiteit was stopte de reeks beelden met afspelen. Dit leidde tot een onmiddellijk onderzoeksresultaat: het verschil in tijdsduur dat het bekijken van de filmpjes door de proefpersonen in beslag nam. Jammer genoeg had de laagdrempeligheid van de onderzoeksopzet tot gevolg dat er geen duidelijke resultaten werden gevonden die de hypothese konden ondersteunen.

\section{Conclusie}

Uit de bovenstaande uiteenzetting valt niet één concrete conclusie te trekken. Aangezien de begrippen kunsttherapie en de functie van kunst nog redelijk jong zijn, wordt er nu nog volop onderzoek gedaan en het blijft natuurlijk ook een kwestie van mening. Hieronder volgen een aantal conclusies die in de gebruikte bronnen zijn getrokken om antwoord te geven op de vraag: wat is het effect van kunst op de 
psychische gesteldheid? Ten eerste schreef de Britse kunstenaar Adrian Hill, de bedenker van de term kunsttherapie in 1942, dat de waarde van kunsttherapie in het volledig in beslag nemen van de geest en ook de vingers ligt, waardoor de vaak afgeremde patiënt zijn creatieve energie de vrije loop kan geven. Dit stelt de patiënt in staat een sterke verdediging op te bouwen tegen zijn tegenslagen. Zo is kunst dus van waarde voor psychologische patiënten, vooral in de revalidatie. Voortrekker van de kunsttherapie uit de Verenigde Staten, Margaret Naumburg [4] en Edith Kramer [5], begonnen hun uitvoering rond dezelfde tijd als Hill. Naumburg, een docent, vond dat kunsttherapie psychoanalytisch georiënteerd is en dat vrije kunstuitdrukking een vorm van symbolische taal is die leidt tot een toename van verbalisatie in de therapie. Edith Kramer, een kunstenares, wees op het belang van het creatieve proces, psychologische verdediging en artistieke kwaliteit: "sublimatie wordt bereikt als beelden gecreëerd worden die succesvol woede, angst of pijn bevatten." Volgens de Federatie Vaktherapeutische Beroepen kun je al tekenend emoties uiten of pijn verwerken. Je kunt positieve veranderingen aanbrengen, eerst op papier, daarna in het eigen leven. Door direct te gaan tekenen, blijf je niet eindeloos praten over je problemen of gevoelens, maar gaat ze werkelijk aan, zodat echte heling plaats kan vinden. Ook diepgaande problemen of trauma's kun je op deze manier doorwerken en verwerken, zodat je meer ontspannen en krachtiger in het leven komt te staan. Kunst heeft op veel verschillende manieren invloed op de psychische gesteldheid van mensen en soms zelfs op de lichamelijke gesteldheid. Het wordt gezien als een therapeutisch middel waarmee je je leven rijker en completer kunt maken. In het boek Kunst als Therapie van Alain de Botton en Armstrong [16] staat dat kunst onze aangeboren gebreken compenseert, in dit geval van de geest. Gebreken die we kunnen omschrijven als psychische tekortkomingen. Het boek van de Botton en Armstrong stelt dat kunst een therapeutisch medium is dat ons kan begeleiden, vermaken en troosten, waardoor we instaat zijn betere versies van onszelf te worden.

\section{Literatuurlijst}

1. Wikipedia, Adrian Hill. https://en.wikipedia.org/wiki/Adria n Hill.

2. Wikipedia, Diverse schrijvers (laatste aanpassing: 2014). Art 
Therapie, Wikipedia. Geraadpleegd op 16 November 2014. http://en.wikipedia.org/wiki/Art th erapy\#History.

3. Wikipedia, Michael Edwards. https://en.wikipedia.org/wiki/Micha el Edwards (art therapist).

4. Wikipedia, Margaret Naumburg. https://en.wikipedia.org/wiki/Marga ret Naumburg.

5. Wikipedia, Edith Kramer. https://en.wikipedia.org/wiki/Edith Kramer.

6. Wikipedia, Robert "Bob" Ault. https://en.wikipedia.org/wiki/Rober t \%22Bob\%22 Ault.

7. Wikipedia, Judith A. Rubin. https://en.wikipedia.org/wiki/Judith A. Rubin.

8. Wikipedia, American Art Therapy Association.

https://en.wikipedia.org/wiki/Ameri can_Art Therapy Association.

9. Wikipedia, Der Blaue Reiter. https://en.wikipedia.org/wiki/Der

Blaue Reiter.

10. Wikipedia, Wassily Kandinsky. https://en.wikipedia.org/wiki/Wassi ly Kandinsky.
11. Wikipedia, Augustv Macke. https://en.wikipedia.org/wiki/Augu st Macke.

12. Wikipedia, Franz Marc. https://en.wikipedia.org/wiki/Franz Marc.

13. Wikipedia, Alexej von Jawlensky. https://en.wikipedia.org/wiki/Alexe j von Jawlensky.

14. Morgenthaler, W., Ein Geisteskranker als Künstler: Adolf Wölfli. 1985: Medusa Verlag.

15. Prinzhorn, H., Bildnerei der Geisteskranken. The Journal of Nervous and Mental Disease, 1923. 58(3): p. 291.

16. De Botton, A. and J. Armstrong, Kunst als therapie. 2013: Terra.

17. EGBG, A.M.F.E., Om in te nemen. 2013: p. 176.

18. Janssen, J.H., Data analyse fysiologisch onderzoek. Om in te nemen, 2013.

19. Engelbregt, H.J. and F.C. Koolen, Kunst versus Placebokunst. 2013: p. 68-73. 